\title{
Kamil Piskała
}

\section{Socjalizm jako spisek}

Urodzony w 1866 roku w niewielkiej mieścinie, jaką było wówczas Busko, Jan Wacław Machajski jest jedną z najciekawszych postaci w dziejach polskiego radykalizmu. Niezwykła była nie tylko jego biografia, pełna sensacyjnych, a czasem wręcz awanturniczych epizodów, lecz również, a może przede wszystkim, jego poglądy polityczne, głoszone wytrwale, ale też - jak wskazywałaby grupa wiernych uczniów i kontynuatorów - bardzo sugestywnie. Rzadko też w dziejach polskiej myśli społecznej znajdujemy autorów, których postać jest szeroko znana wśród badaczy zagranicznych. Twórczość Machajskiego stała się przedmiotem dociekań niemałej grupy zachodnich historyków i socjologów ${ }^{1}$, a od jego nazwiska ukuto nawet, dość rozpowszechniony, termin Makhaevism ${ }^{2}$ (w wersji polskiej najpopularniejsza jest „machajszczyzna”, rzadziej jako „machajewizm” lub „machajewszczyzna”).

Wydawałoby się więc, że Machajski powinien być postacią w Polsce dobrze znaną, a jego biografia i światopogląd gruntownie przebadane. Nic bardziej błędnego! Machajski stał się bohaterem legendy, której

1 W sposób najzwięźlejszy, ale też niewyczerpujący, o zainteresowaniu Machajskim zagranicą pisze Leszek Gawor, zob. L. Gawor, Machajskiego teoria socjalistycznej rewolucji, „Wschodni Rocznik Humanistyczny” 2007, t. 4.

2 P. Avrich, What is "Makhaevism”?, www.libcom.org/history/what-makhaevism-paul-avrich [data dostępu: 15 grudnia 2012]. 
kontury coraz mocniej zacierają się w pamięci - wiemy o jej istnieniu, rodzi w nas może jakieś niesprecyzowane uczucia, lecz nie jesteśmy w stanie powtórzyć już jej fabuły. Zapomnienie to często próbuje się tłumaczyć faktem, że był to autor „niebezpieczny” dla rządzących przez cztery i pół dekady tzw. Polską Ludową, a wobec tego wymazanie Machajskiego z kart historii byłoby poniekąd konsekwencją „urzędowej” decyzji ${ }^{3}$. Bez wątpienia lektura pism Machajskiego mogła sprzyjać krytyce „realnego socjalizmu”, nie było też przypadkiem, że oficjalnie potępiono jego poglądy w Związku Radzieckim w latach trzydziestych. Jednak jest to tylko, jak sądzimy, część wyjaśnienia. Powody zapomnienia Machajskiego są również znacznie bardziej prozaiczne. Po pierwsze, należałoby wskazać na trudność związaną z jednoznacznym zakwalifikowaniem go do jakiejkolwiek szerszej tradycji intelektualnej. Po wtóre natomiast - i jest to chyba rzecz kluczowa - podkreślić należy niemal zupełną niedostępność jego tekstów, których nie wznawiano i nie tłumaczono na język polski (publikował niemal wyłącznie po rosyjsku) ${ }^{4}$.

Do zmiany tej sytuacji, a tym samym również do lepszego poznania poglądów Machajskiego, wydatnie przyczynić może się wydany niedawno tekst pt. Robotnik umystowy (1911), opracowany i poprzedzony wstępem przez Lecha Dubla. Robotnik umystowy $(1911)^{5}$ nie był dotychczas publikowany, rękopis, którego forma wyraźnie wskazuje na to, że Machajski przygotowywał go do druku, jest przechowywany w amsterdamskim Międzynarodowym Instytucie Historii Społecznej w spuściźnie Maksa Nomada $^{6}$ (znanego też jako Max Nacht) - najwybitniejszego ucznia i współpracownika Machajskiego ${ }^{7}$. Nim jednak przejdziemy do omówienia samego tekstu, recenzencki obowiązek zmusza do powiedzenia kilku słów o poprzedzającym go obszernym, złożonym z dwóch rozdziałów, wstępie pióra wspomnianego już profesora Dubla.

3 Zob. L. Dubel, Wstęp, [w:] J.W.Machajski, Robotnik umystowy 1911, Zamość 2012, s. 45-46.

4 Udało nam się zlokalizować jedynie trzy stosunkowo łatwo dostępne w języku polskim teksty Machajskiego: Socjalizm państwowy, „Zdanie” 1987, nr 12; Religia socjalistyczna a walka robotnicza oraz Bilans burżuazyjnej rewolucji rosyjskiej, [w:] Anarchizm i anarchiści na ziemiach polskich do roku 1914, red. H. Rappaport, Warszawa 1981.

5 Pod tym samym tytułem (Umstwiennyj raboczij) ukazała się jedna z najważniejszych broszur Machajskiego, wydana w Genewie w 1905 roku.

6 Zob. W. Portmann, Die wilden Schafe: Max und Siegfried Nacht, Münster 2008.

7 L. Dubel, Stowo od redaktora w stulecie powstania pracy Machajskiego, [w:] J. W. Machajski, Robotnik umystowy..., s. 60-61. 
Podjęta została tutaj próba zaprezentowania życiorysu Machajskiego, a także rekonstrukcji najważniejszych wątków obecnych w jego myśli społecznej. Niestety, jest to tylko „próba”, momentami nawet nieco nieporadna. Po uważniejszym przyjrzeniu okaże się, że ów wstęp jest niemal w całości kompilacją fragmentów wydanej przez autora kilka lat wcześniej książki Zapomniany prorok rewolucji: szkic o Janie Wactawie Machajskim $^{8}$. Sama książka, mówiąc oględnie, nie zadowoli bardziej dociekliwych czytelników, i należy ubolewać, że nie doczekała się wnikliwej i krytycznej recenzji. Sytuację pogarsza fakt, że dobór fragmentów, które przekopiowano do napisanego przez Dubla wprowadzenia i ich kompozycja nie są zbyt udane, co powoduje wiele niejasności i niepotrzebnie komplikuje wiele wątków. Dodajmy do tego niezgodność tytułu jednego z podrozdziałów (2.1. Klasyfikacja ideowa doktryny) z zawartą w nim treścią oraz momentami skandaliczny poziom edytorski (wątpiącym proponujemy zerknąć na strony 37 i 38, aby zobaczyć jak wkomponowano fotografię w tekst, lub na stronę 46), co może czasami utrudniać lekturę.

Załóżmy jednak, że wytrwały czytelnik przebrnął przez pierwsze sześćdziesiąt stron i dociera do zasadniczej części książki, czyli do tekstu Robotnik umystowy (1911), który sto lat temu wyszedł spod pióra Machajskiego. Tutaj natrafia trudność nieco innego rodzaju - jest nią styl Machajskiego. Przyznać trzeba, że nawet dla kogoś, kto obyty jest z językiem epoki i ówczesną literaturą socjalistyczną czy anarchistyczną (bo w dialogu z tymi dwiema tradycjami autor prowadzi swoje rozważania) jest to lektura trudna i wymagająca dużego skupienia. Machajski pisze w sposób chaotyczny, wciąż miesza wątki, brak mu widocznej i przemyślanej struktury argumentacji, a od precyzji wyrażenia ważniejszy jest retoryczny efekt ${ }^{9}$. Mimo to warto podjąć próbę przeprawienia się przez ten trudny tekst, zawarta jest w nim jak sądzę zdecydowana większość najważniejszych dla Machajskiego intuicji teoretycznych.

Już pierwsze zdanie w zwięzły sposób prezentuje tezę, wokół której obracają się rozważania Machajskiego: „Socjaliści zawsze i wszędzie sta-

8 Tegoż, Zapomniany prorok rewolucji: szkic o Janie Wactawie Machajskim, Lublin 2008.

9 Zygmunt Zaremba, jeden z przywódców międzywojennej PPS, w pracy o Machajskim pisze: „Jego pisarstwo jest ciężkie, często zagmatwane, pełne powtórzeń i dygresji. Zaprawione jest przy tym piekącą zjadliwością, gorzkim sarkazmem, a nawet nienawiścią do tych, których zwalczał" - Z. Zaremba, O Machajskim, http://lewicowo.pl/o-machajskim/ [data dostępu: 15 grudnia 2012] (jest to fragment większej pracy: Stowo o Wactawie Machajskim, Paryż 1967).

Machajski pisze w sposób chaotyczny, wciąż miesza wątki, brak mu widocznej i przemyślanej struktury argumentacji, a od precyzji wyrażenia ważniejszy jest retoryczny efekt 
rają się by nie wykorzystywać buntowniczych nastrojów robotników dla zaspokojenia potrzeb samych robotników"10. Machajski dostrzega zasadniczą różnicę między postulatami, które znajdują się w programach partii socjalistycznych, a rzeczywistymi interesami robotników. W tym pierwszym wypadku chodzi przede wszystkim o dążenie do zreformowania, zdemokratyzowania istniejącego ustroju i oszczędzanie „rewolucyjnej energii” na czas ostatecznej i raczej odległej walki o realizację socjalizmu. Klasa robotnicza natomiast w spontaniczny sposób dąży do poprawy swojego położenia materialnego, przede wszystkim poprzez uzyskanie wzrostu płac. Dalej Machajski dowodzi, że preferencja dla legalnych form walki, obawa przed otwartym i masowym wystąpieniem proletariatu oraz ciągłe przypominanie o „historycznej konieczności” wynika w rzeczywistości nie z „rozwagi” i „dalekowzroczności” przywódców socjalistycznych, lecz z dojmującego lęku przed prawdziwą rewolucją. Czy jednak owa zdrada robotników przez partyjnych przywódców wynika tylko z ich perfidii? To proste wyjaśnienie nie wystarcza Machajskiemu - szuka innych przyczyn takiego postępowania socjalistów. Zastanawiając się nad pochodzeniem liderów i ich miejscem w strukturze społecznej, dostrzega, że zdecydowana większość z nich to inteligenci, starannie wykształceni, żyjący ze „sprzedaży” swej wiedzy - czy to jako naukowcy, publicyści albo urzędnicy, czy też jako „zawodowi rewolucjoniści”, utrzymywani przez partię. A wobec tego ruch socjalistyczny realizuje de facto nie tyle interesy robotników, co interesy kierujących nim inteligentów.

Zasadnicza linia podziału społeczeństwa, dowodzi dalej Machajski, nie przebiega wcale pomiędzy ludźmi pracy najemnej a garstką kapitalistów (jak chcą marksiści), lecz pomiędzy tymi, którzy żyją z pracy fizycznej a tymi, którzy dzięki swojej wiedzy lub kapitałowi mogą owej pracy uniknąć.

Nauka socjalistyczna - to tarcza ochronna pasożytnictwa całego wykształconego społeczeństwa burżuazyjnego. Rokrocznie we wszystkich krajach szkoły średnie i wyższe kończą tysiące, dziesiątki tysięcy ludzi, którzy zajmą w społeczeństwie uprzywilejowane stanowiska, zwalniające ich od brzemienia pracy fizycznej. Spotykają się oni z pracą tylko jako jej organizatorzy, rządzący, dowódcy. Jedynie najmniej znaczna mniejszość tych wykształconych panów zajmie niezależne stanowiska samodzielnych przedsiębiorców - kapitalistów. Znaczna większość, tworząca klasę, tak zwaną zawodową inteligencję, otrzymuje swój uprzywilejowany dochód nie z kapitału własnego, jako zysk przedsiębiorcy wyciśnięty bez-

10 J. W. Machajski, Robotnik umystowy..., s. 64. 
pośrednio z robotników, a jako „pensja”, „honorarium” otrzymywane przez każdego zawodowego inteligenta ${ }^{11}$.

Warto na marginesie głównego wątku rozważań dodać, że Machajski wyraźnie dostrzegał zjawisko dziedziczenia statusu społecznego i międzypokoleniowej transmisji w rodzinach inteligenckich tego, co w terminologii Pierre’a Bourdieu zwykło się dziś nazywać „kapitałem kulturowym i społecznym ${ }^{12}$ :

[Z] ojca na syna przechodzi w klasie robotniczej wieczna niewolnicza służba i nieunikniona, towarzysząca jej niewiedza; w klasach posiadaczy w spadku z ojca na syna przechodzi wyższa kultura, coraz bardziej słodsze życie po pańsku w komforcie i luksusie [...]. „Szlachetni” potomkowie panów jeszcze zanim pojawili się na świecie, już byli uznani za jedynie zdolnych do pracy umysłowej, jedynie właściwych do zajmowania kierowniczej roli w społeczeństwie ${ }^{13}$.

Zajęcie uprzywilejowanej pozycji w społeczeństwie może być więc konsekwencją posiadania kapitału, ziemi lub wiedzy. Jak jednak wyjaśnić zaangażowanie inteligencji w socjalizm i dążenie do obalenia, stosunkowo wygodnego dla niej, systemu kapitalistycznego? Machajski uważał, że ruch socjalistyczny w rękach inteligentów stanowi narzędzie, za pomocą którego toczą walkę z burżuazją i ziemiaństwem. Dowodów potwierdzających tę tezę dopatrywał się w uwagach na temat przyszłego ustroju socjalistycznego obecnych w wystąpieniach liderów II Międzynarodówki. Obalenie kapitalizmu miało doprowadzić do zniesienia prywatnej własności środków produkcji, program socjalistyczny milczał jednak - jak wskazywał Machajski - na temat możliwości wywłaszczenia posiadaczy wiedzy i wykształcenia. Tym samym, w tak pomyślanym społeczeństwie socjalistycznym faktyczna władza znajdzie się w rękach inteligencji, położenie robotników zaś nie ulegnie poważniejszej zmianie.

Rewolucja socjalistyczna, socjalistyczne „wywłaszczenie” [...] wiekowej niewoli mas robotników nie likwiduje i jej podstaw nie dotyczy. Dwie odwiecznie istniejące rasy panów i niewolników - pozostają również w ustroju socjalistycznym. Do pierwszej należy cała inteligencja proletariacka, cały świat naukowy, wszyscy ci, którzy urodzeni i wychowywani byli po to by kierować i dowodzić, ponieważ to oni posiedli tajemnice nowoczesnej produkcji i posiadają wiedzę niezbędną

11 Tamże, s. 73-74.

12 P. Bourdieu, Dystynkcja: spoteczna krytyka wtadzy sądzenia, tłum . P. Biłos, Warszawa 2006.

13 J. W. Machajski, Robotnik umystowy..., s. 75. 
do zarządzania. Wywłaszczenie kapitalistów milionom współczesnych niewolników wiedzy tej nie daje. Oni, jak dawniej, pozostają mając status niższej rasy ludzi zdolnych do wykonywania tylko czarnej pracy [...] fizycznej ${ }^{14}$.

Machajski obszerne fragmenty pracy poświęca na przytoczenie argumentów potwierdzających, że socjalizm jest jedynie inteligenckim spiskiem, który miałby na dodatek zostać zrealizowany rękami samych robotników. Spośród nich wymienić można przede wszystkim: niechęć socjalistów do wspierania ekonomicznych postulatów proletariatu, zbyt wąską definicję grupy wyzyskiwaczy (bogaty inteligent i jego lokaj to tacy sami „proletariusze” - dowodzi Machajski), odrzucenie postulatu zrównania wynagrodzeń w ustroju socjalistycznym i poparcie socjalistów dla utrzymania instytucji dziedziczenia. W tym ostatnim wypadku Machajski jednak bardziej chyba obawia się dziedziczenia wspomnianego już kapitału kulturowego, mniej zaś dziedziczenia majątku. Jak ten problem miałby zostać rozwiązany w przyszłości? Tutaj wyraźnie brakuje mu odpowiedzi.

W ustroju socjalistycznym cywilizacja i kultura pozostają własnością monopolistyczną dziedziczną inteligencji. Świat grabieżczy znajduje w ustroju socjalistycznym jedynie nową formę swojego panowania ${ }^{15}$.

Zresztą, jak wkrótce dodaje Machajski, buńczuczne, pełne rewolucyjnego frazesu zapowiedzi socjalistów z roku na rok stają się coraz mniej żarliwe, a realizacja wielkich planów odkładana jest na coraz dalszą przyszłość.

Dzieje się tak, ponieważ burżuazja poprawnie rozpoznała rzeczywisty charakter ruchu socjalistycznego. Wobec tego najlepszym sposobem na oddalenie niebezpieczeństwa rewolucji okazało się wciagnięcie rosnącej liczebnie inteligencji do podziału zysków płynących z wyzysku ludzi o „zrogowaciałych dłoniach”. Trudno nie oprzeć się wrażeniu, że taka analiza ewolucji struktury klasowej w toku rozwoju kapitalizmu jest raczej naiwna; nie można jednak odmówić Machajskiemu trafnego, choć może niezbyt odkrywczego spostrzeżenia, mówiącego o malejącej „bojowości” ówczesnych partii socjalistycznych. Dowodzi on dalej, że poprawa położenia materialnego inteligentów bezpośrednio wpłynęła też na ewolucję programu socjalistycznego. Wątki utopijne silnie obecne w okresie narodzin ruchu, a także skłonność do całkowitej negacji porządku kapitalistycznego, zostały zastąpione przez umiarkowanie w doborze środków,

14 Tamże, s. 84.

15 Tamże, s. 91. 
deklaracje o „naukowości” marksizmu oraz podkreślenie pozytywnych cech kapitalizmu:

Stopniowo marksiści zmuszają wszystkich socjalistów, cały swój „proletariat” do uznania i czczenia „nieocenionych zasług historycznych” ustroju kapitalistycznego, i z biegiem czasu po całym świecie rozpowszechnia się marksistowska apoteoza kapitalizmu: ustrój kapitalistyczny ogłoszony jest za kołyskę przyszłego najbardziej idealnego ustroju ${ }^{16}$.

Krytyka Machajskiego skierowana jest przeciwko dominującej wówczas marksistowskiej ortodoksji. Przywiązanie do kategorii „historycznej konieczności” pozbawiało socjalizm prawdziwie rewolucyjnego ducha. Deterministyczny ekonomizm, reprezentowany w krańcowej formie przez tzw. legalnych marksistów w Rosji, ale przecież nieobcy również wielu niemieckim socjaldemokratom, paradoksalnie zamieniał rewolucyjną teorię w apologię kapitalizmu, albo - w najlepszym wypadku - w umiarkowany reformizm. Pod koniec swoich rozważań Machajski formułuje tezę o dwóch wykluczających się wzajemnie celach ruchu socjalistycznego. Pierwszy z nich to cel „oficjalny”, obecny w masowej propagandzie, pismach teoretyków i partyjnych programach. Jest nim oczywiście ustrój społecznej sprawiedliwości, realizujący zasady autonomii jednostki, równości i nieskrępowanego samorozwoju. Cel drugi, wstydliwie skrywany, przyświecający socjalistom w rzeczywistości, to ujarzmienie proletariatu.

Prawdziwy cel współczesnego socjalizmu - to wyniesienie jednej części „swojego” proletariatu to jest inteligencji, do statusu klasy panującej, a następnie, osadzenie na plecach robotników nowych, świetnie rozmnażających się pasożytów ${ }^{17}$.

Ocena dorobku Machajskiego bez wątpienia stanowi duży problem, o czym świadczą też rozbieżne opinie formułowane przez różnych badaczy. Machajski - czego doskonałym świadectwem jest Robotnik umystowy (1911) - w swoich tekstach obficie rozdawał kuksańce wszystkim dookoła, nie może dziwić więc, że niektóre z tych polemicznych „ciosów”, z dzisiejszej perspektywy, trafiają zaskakująco celnie. Jednocześnie pamiętać trzeba, że nie był autorem szczególnie systematycznym, a część jego krytyk ma kiepskie osadzenie w fundamentach jego myśli; fundamentach, które, gdy przyjrzeć się im bliżej, okazują się momentami zaskakująco płytkie i kruche.

16 Tamże, s. 109.

17 Tamże, s. 117.

Machajski w swoich tekstach obficie rozdawał kuksańce wszystkim dookoła, nie może dziwić więc, że niektóre z tych polemicznych "ciosów”, z dzisiejszej perspektywy, trafiają zaskakująco celnie 
Oczywiście nie należy czynić z tego Machajskiemu jakiegoś poważnego zarzutu, sam przecież nie chciał odgrywać roli subtelnego teoretyka, a raczej agitatora i architekta „zmowy robotniczej” ${ }^{\prime 18}$, walczącej - w przeciwieństwie do partii socjalistycznych - o „prawdziwe" interesy proletariatu. Niestety, nie wszyscy badacze o tym pamiętają - biorąc za dobrą monetę rozproszone polemiczne uwagi Machajskiego, awansują go do wąskiego grona wyprzedzających swoją epokę wizjonerów, których pisma udzielają trafnej odpowiedzi na szereg ważkich i wciąż dyskutowanych pytań. Przykładem takiej bezkrytycznej, a może nawet momentami apologetycznej, postawy jest niestety wspomniany powyżej profesor Dubel.

Dostrzeżenie przez niego w Machajskim prekursora teorii „nowej klasy" avant la lettre wydaje się pewnym nieporozumieniem. Razić musi, po pierwsze, naiwność dokonywanego przez autora Robotnika umystowego opisu struktury klasowej społeczeństwa, analityczna bezużyteczność większości formułowanych przez niego pojęć, czy wreszcie niemal całkowita rezygnacja z prób empirycznego potwierdzenia słuszności stawianych tez. Machajski zupełnie nie dostrzega „stopniowalności” wykształcenia - jego zdaniem albo się je posiada, albo nie - $\mathrm{i}$ bezpośrednio wiąże podział ról $\mathrm{w}$,socjalistycznym” porządku z pochodzeniem klasowym. W teoriach „nowej klasy" i wszelkich próbach teoretycznego opisania zjawiska biurokratyzacji aparatu państwowego w krajach realnego socjalizmu kwestia społecznego pochodzenia ma drugorzędne znaczenie, podobnie jak i formalne wykształcenie osób zajmujących uprzywilejowane stanowiska w takich systemach. Wspólna z przewidywaniami Machajskiego byłaby więc przede wszystkim konstatacja mówiąca o tym, że porewolucyjna nacjonalizacja gospodarki nie przyniesie wcale wyzwolenia robotników, lecz doprowadzi jedynie do wykształcenia się nowej klasy wyzyskującej proletariat, tym razem za pomocą udziału w aparacie władzy ${ }^{19}$. Jak widać więc, szukanie łatwych analogii, choć efektowne, może prowadzić do zbyt pochopnych wniosków.

Przy referowaniu poglądów Machajskiego na drugi plan spychana jest zazwyczaj prowadzona przez niego krytyka przemian w działalności i taktyce partii socjalistycznych. Wydaje się natomiast, że to właśnie ta

18 Zob. L. Dubel, Idea Zmowy Robotniczej w ujęciu J. W. Machajskiego, „Annales UMCS” 1988, vol. XXXV, sectio G.

19 Podobne opinie, choć wyprowadzone z zupełnie innych przesłanek, formułował w tamtym okresie również Edward Abramowski. W wypadku Abramowskiego mamy jednak do czynienia z rozważaniami cechującymi się zdecydowanie wyższą dyscypliną teoretyczną, wewnętrznie spójną argumentacją i mocnym umocowaniem w szerszym projekcie filozofii społecznej, zob. E. Abramowski, Socjalizm a państwo, [w:] tegoż, Pisma, t. 2, Warszawa 1924. 
część jego dorobku zasługuje dziś na szczególną uwagę. Zresztą odnieść można wrażenie, że sam Machajski gdy przechodzi do omawiania tej problematyki, staje się - co do niego mało podobne - nieco uważniejszy, waży słowa i usiłuje w bogatszy sposób argumentować swoje stanowisko. Krytyka Machajskiego skierowana jest przeciwko ówczesnej ortodoksji marksistowskiej, którą znał dobrze nie tylko z pism Kautsky'ego, ale również Plechanowa. W pewnym sensie antycypuje ona wszystkie najważniejsze zarzuty, jakie do dziś wysuwa się wobec „marksizmu II Międzynarodówki”, czy może, posługując się sformułowaniem Andrzeja Walickiego, marksizmu „necessarystycznego” ${ }^{20}$.

Machajski dostrzegał wyraźnie, jak już zauważyliśmy, słabnięcie radykalizmu socjalistycznych przywódców oraz narastającą przepaść między oficjalnymi deklaracjami a faktyczną polityką partii. W obiektywistycznym odczytaniu marksizmu, na pierwszy plan wysuwającym kategorię „historycznej konieczności”, Machajski widział nowy wariant naturalizmu, próbę ujęcia procesu historycznego w narzucone niejako z zewnątrz prawa. Stąd bierność partii socjalistycznych, koncentracja na walce o liberalne reformy polityczne i odsunięcie w daleką przyszłość realizacji ideału socjalistycznego (nabierającego coraz bardziej mitycznych, quasi-religijnych kształtów ${ }^{21}$ ). Przyczynę ewolucji widział Machajski w coraz pełniejszym podporządkowywaniu sobie ruchu socjalistycznego przez inteligencję. Jak byśmy jednak nie ocenili tego wyjaśnienia, sam opis przemian, jakim ulegały wówczas partie II Międzynarodówki, okazuje się niezwykle trafny. W tym kontekście żałować należy, że nie dysponujemy tłumaczeniem jednej z jego wcześniejszych prac - Ewolucja socjaldemokracji. Była to obszerna polemika z Bernsteinem i rodzącym się w Niemczech nurtem rewizjonistycznym. Trocki, wówczas przebywający na zesłaniu nieopodal Wilujska, gdzie osadzono Machajskiego, wspominał później, że ta bardzo krytyczna w swej wymowie broszura „cieszyła się w koloniach zesłańczych dużym powodzeniem”22. Z czasem

20 A. Walicki, Marksizm i skok do królestwa wolności: dzieje komunistycznej utopii, Warszawa 1996.

21 Zob. tegoż, Zarys myśli rosyjskiej: od oświecenia do renesansu religijno-filozoficznego, Kraków 2005, s. 410; Machajski w innym tekście pisał: „Socjaliści dumni są z tego, że w przeciwieństwie do klechów umieścili królestwo niebieskie na ziemi. Chełpią się na próżno. Ziemski raj socjalistów jest równie daleki i niedostępny dla żywych ludzi, jak i wszelki raj niebiański.” - J. W. Machajski, Religia socjalistyczna a walka robotnicza, http://lewicowo.pl/religia-socjalistyczna-a-walka-robotnicza/ [data dostępu: 15 grudnia 2012].

22 L. Trocki, Moje życie: próba autobiografii, tłum. J. Barski, S. Łukomski, Warszawa 1990, s. 144.

W obiektywistycznym odczytaniu marksizmu, na pierwszy plan wysuwającym kategorię „historycznej

konieczności”, Machajski widział nowy wariant naturalizmu, próbę ujęcia procesu historycznego

w narzucone niejako

z zewnątrz prawa 
jednak Machajski poszedł w swej krytyce dalej, dowodząc, że „ortodoksyjnego” marksistę Kautsky’ego i rewizjonistę Bernsteina dzieli stosunkowo niewiele, obydwie koncepcje programowe są bowiem oparte na tych samych założeniach i stanowią próbę racjonalizacji inteligenckich postulatów ${ }^{23}$. W świetle tego, co działo się z niemiecką socjaldemokracją po 1917 roku, opinia o ukrytym pokrewieństwie obydwu tych nurtów wydaje się w dużej mierze trafna.

Robotnik umystowy (1911) to jeden z nielicznych obszerniejszych tekstów Machajskiego, który jest dostępny polskiemu czytelnikowi. Jest to praca z „dojrzałego” okresu jego twórczości, a wobec tego raczej reprezentatywna - zawiera w zasadzie większość najistotniejszych spośród podejmowanych przez niego wątków. Choć możemy narzekać na opracowanie, poziom edytorski i dość wysoką cenę, to jednak sam fakt wydania książki należy ocenić ze wszech miar pozytywnie. Za jej sprawą mamy szansę lepiej poznać ważną, a nieco zapomnianą, kartę z historii radykalnej myśli społecznej. Należy wrazić nadzieję, że jest to zapowiedź wzrostu zainteresowania polskich badaczy i badaczek postacią Machajskiego, a może także publikacji kolejnych jego tekstów.

Jan Wacław Machajski, Robotnik umystowy 1911, oprac. L. Dubel, tłum. H. Sajewicz, Zamość 2012.

23 Zob. A.A. Kamiński, Socjalizm jako wymyst inteligencji: o życiu i pogladach Jana Wactawa Machajskiego, „Nauki Humanistyczne” 2003, t. 8, s. 59. 
Kamil Piskała (ur. 1988) - doktorant w Katedrze Najnowszej Historii Polski UŁ; studiuje również politologię w ramach MISH. Jego zainteresowania badawcze koncentrują się wokół historii polskiej lewicy XIX i XX w., symbolicznych aspektów funkcjonowania ruchu robotniczego, a także tradycji środkowoeuropejskiego marksizmu. Ponadto zajmuje się dziejami polskiej międzywojennej myśli politycznej, teoriami rewolucji oraz peryferyjnymi dyskursami modernizacyjnymi pierwszej połowy XX stulecia. Młodość spędza zgarbiony nad zakurzonymi papierami w archiwum albo starymi książkami w bibliotecznych czytelniach. Związany z łódzkim klubem „Krytyki Politycznej”, w „Praktyce Teoretycznej” redaktor tematyczny w zakresie nauk historycznych.

\section{Dane adresowe autora:}

Kamil Piskała

kamil.piskala@gmail.com

Katedra Najnowszej Historii Polski UŁ

ul. Kamińskiego 27a, 90-219 Łódź

e-mail: kamil.piskala@gmail.com

\section{Cytowanie:}

K. Piskała, Socjalizm jako spisek, „Praktyka Teoretyczna” nr 6/2012, http://www.praktykateoretyczna.pl/PT_nr6_2012_Roza_Luksemburg/21.Piskala.pdf (dostęp dzień miesiąc rok)

Author: Kamil Piskała

Title: Socialism as a Conspiracy 